University of Nebraska - Lincoln DigitalCommons@University of Nebraska - Lincoln

Textile Society of America Symposium Proceedings

Textile Society of America

2018

The Techniques of Samitum. Based on a reconstruction of a silk from the Oseberg burial

Åse Eriksen

Follow this and additional works at: https://digitalcommons.unl.edu/tsaconf

Part of the Art and Materials Conservation Commons, Art Practice Commons, Fashion Design Commons, Fiber, Textile, and Weaving Arts Commons, Fine Arts Commons, and the Museum Studies Commons

This Article is brought to you for free and open access by the Textile Society of America at DigitalCommons@University of Nebraska - Lincoln. It has been accepted for inclusion in Textile Society of America Symposium Proceedings by an authorized administrator of DigitalCommons@University of Nebraska - Lincoln. 


\section{The Social Fabric: Deep Local to Pan Global}

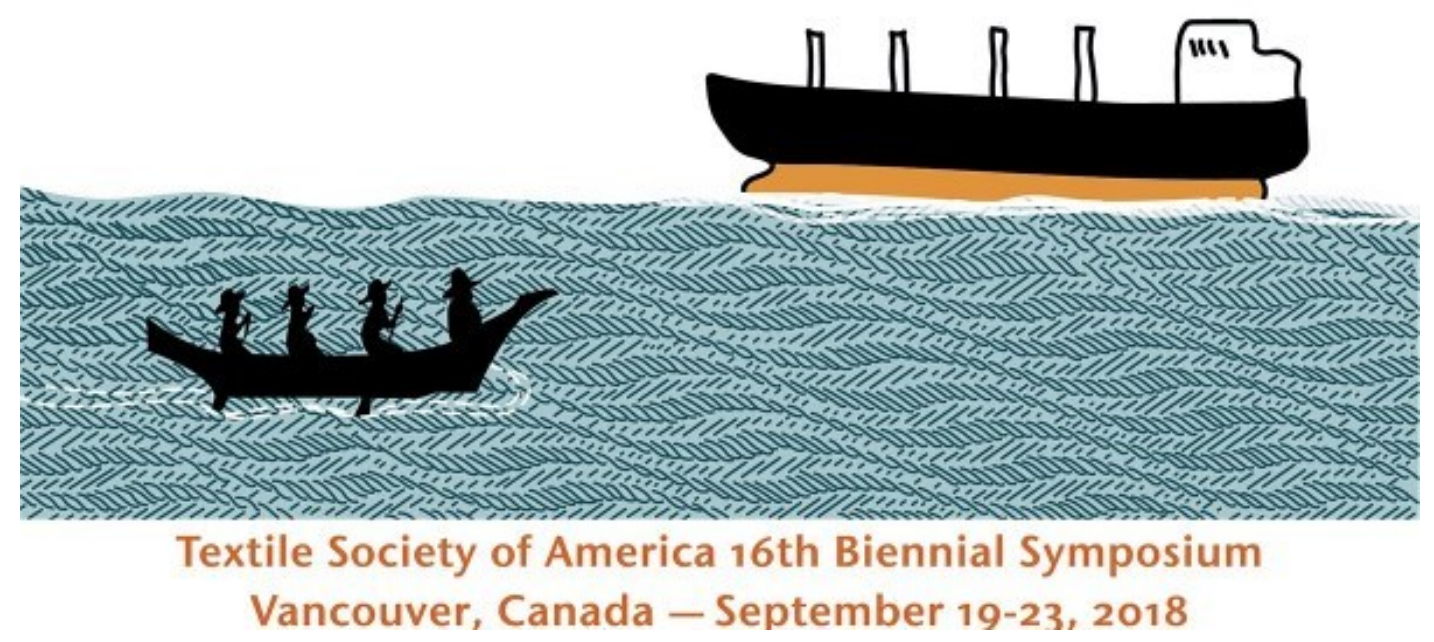

Published in Textile Society of America Symposium Proceedings 2018

Presented at Vancouver, BC, Canada; September 19 - 23, 2018

https://digitalcommons.unl.edu/tsaconf/

Copyright $@$ by the author(s). 


\title{
The Techniques of Samitum. Based on a reconstruction of a silk from the Oseberg burial
}

\author{
Åse Eriksen \\ ase.eriksen@hotmail.com
}

As a student 1977-82 at the textile department at the Art and Craft school, now the University in Bergen, I became interested in the weaving structures that could give me pattern and figures in a Nordic flat loom. By adjusting the, heddles, shafts and reed I got a two sheds or a double shed when I pressed one pedal in the loom. I could then weave techniques as damask and double cloth by picking the pattern directly in the warp.

In "A History of Textile Art" by the Swedish researcher Agnes Geijers I found drawings of two historic weave structures for pattern weaving, that suits the system, and could be woven with double sheds. ${ }^{1}$ The first, called samitum figure 1 , I could easy weave with two sheds, but the Chinese structure, called Jin figure 1, was so dense that I need another working method for it.

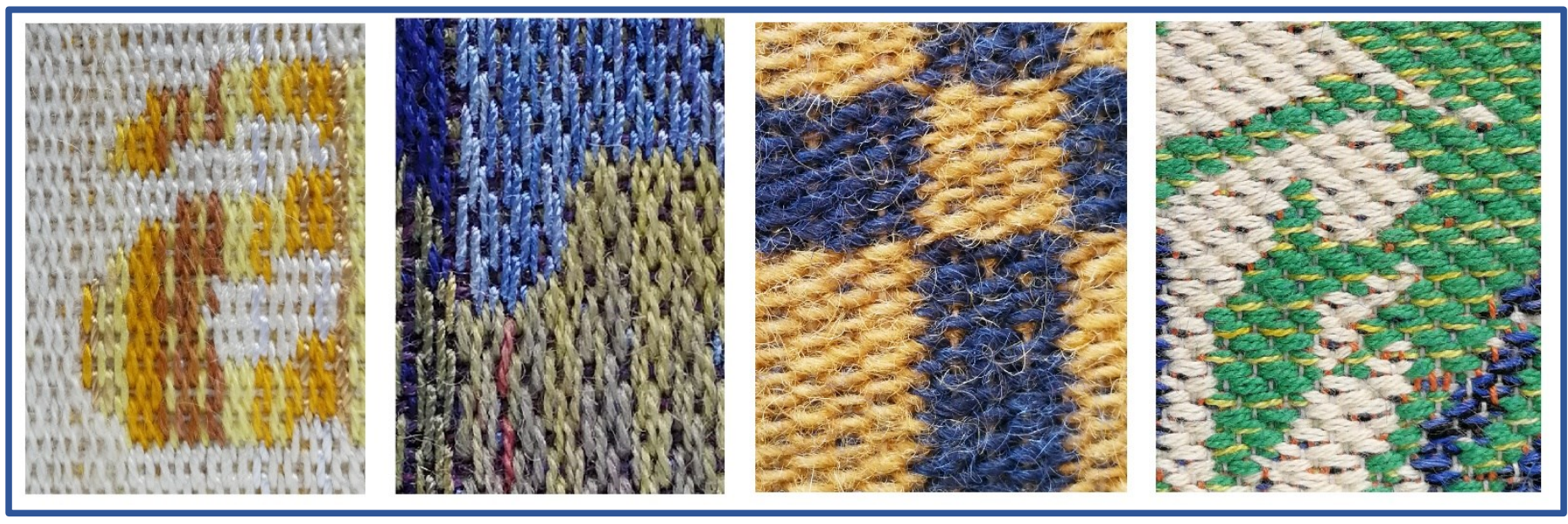

Figure 1. From right, warp faced compound tabby and twill. Weft faced compound tabby and twill, known as taquete and samitum. Photo and samples by the author.

This were practical studies, done for using the techniques in modern hand weaving, as my tool in making contemporary art. It is interesting to look back, because I was not interested in the pattern in these historical fabrics and at the time I did not even note that these fabrics was in silk. My first attempt to weave the Jin was with two woolen warps.

I have since 1995 done commissions for the Norwegian Church, making clothes and liturgical textiles, all done in jin or warp faced compound weaves, twill and tabby. In addition I have also used Han-damask. Last year I saw a historical Jin silk, for the first time, in the Hermitage Museum in St. Petersburg.

The structures and the movement of the threads in samitum and jin are the same, except for the fact that they are turned 90 degree from each other. What is warp in one is weft in the other, and the pattern is in respectively, in the weft and in the warp. Is there a connection? Is there anything in the way of weaving the structures that will tell the story of this transition? -

\footnotetext{
${ }^{1}$ Agnes Geijer, Ur textilkonstens historia. 4. opplag. Gidlunds Förlag, Ljubliana, 2006, 74 -75.
} 
Was Jin in use before taquete, which is the predecessor for samitum, or was there an earlier more widespread stadium of the binding, that could lead to both, or are they similar by coincidence?

In 1980, I tried without success to see the samitum fragments from in the Osebergburial in Norway. Over 110 small fragments samitum silk, belonged to 15 different fabrics, followed the two women in their grave. Together with a collection of other costumes, textiles, tools for making textiles and with a big amount of wooden items, such as the Oseberg Viking ship, carts and sleds, beds and kitchen utensils, made this grave is the richest from the Viking age. The grave from 834 was unearthed in 1904, it was published from 1917-1928, but the textiles not before $2006 .^{2}$

My attempt at that time did not succeed. In 2013 I designed and wove a coat for the bishop in Tønsberg, from the same area were the samitum silk was found in the grave in Norway. I was looking for some textiles to inspire my work. The same year I meet Marianne Vedeler, professor at the Museum of Cultural History in Oslo, and she invited me to look at the silk fragments in the archives. She guided me in the collections, of as many as 110 small samitum fragments. It has been organized and reorganized through many years and researchers. My interest was just once try to weave one of these silks, looking and feeling the materials the Vikings once used.

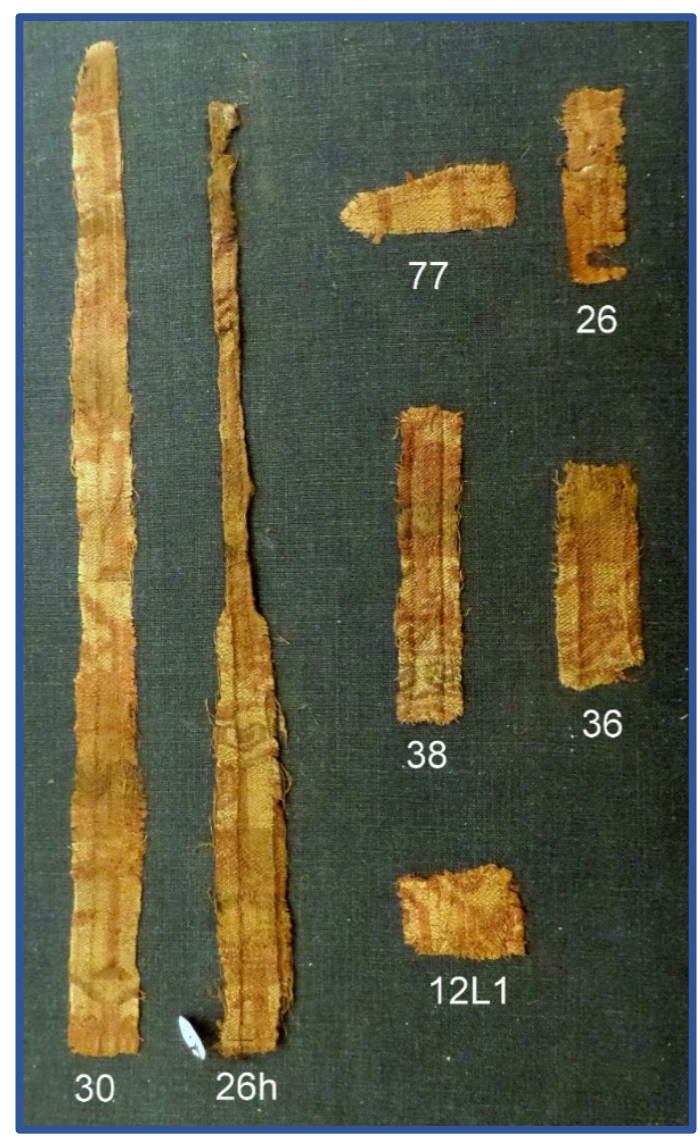

Figure 2. Fabric number 3, one of the 15 from in the Oseberg grave outside Tønsberg in Norway. Six of the seven fragments used for the reconstruction. Photo the author.

\footnotetext{
${ }^{2}$ Christensen Arne Emil og Margareta Nockert (red.) Osebergfunnet, bind IV. Tekstilene. Kulturhistorisk museum, Universitetet i Oslo, Oslo, 2006.
} 
Of course, I was interested in history for these silk fragments, but that is not the issue in here, for more information in "Silks for the Vikings" by Marianne Vedeler. ${ }^{3}$ Some of the more known silks was at display in the Museum and was not possible to study, so Marianne suggested that I could concentrate at fabric number 3.

These seven pieces on figure 2 belong to the same fabric, they are between 1,5 and $2 \mathrm{~cm}$ wide and 2 and $27 \mathrm{~cm}$ long. Both warp and weft are in silk, as it seems also wild silk by the look of the uneven wefts. There are between 36-40 warp ends per. cm, and between $60-80$ wefts per $\mathrm{cm}$. The fragments are attached to the grey cloth, except the one with the white label that has been loosened and could be turned so that the hidden side could be seen. Most of the samitumsilks from this collection was used with the backside of the original fabric out. The what is supposed to be the front side of fragment number $26 \mathrm{~h}$, with the white label, shows that the weft is worn all over the width, meaning that these trimmings was the last end of use and reusing of this fabric.

In order to find the pattern on the fabric the pieces could not be puzzled together, but every little piece from a fabric with a repeated pattern will contain a bit of the pattern repeat unit.

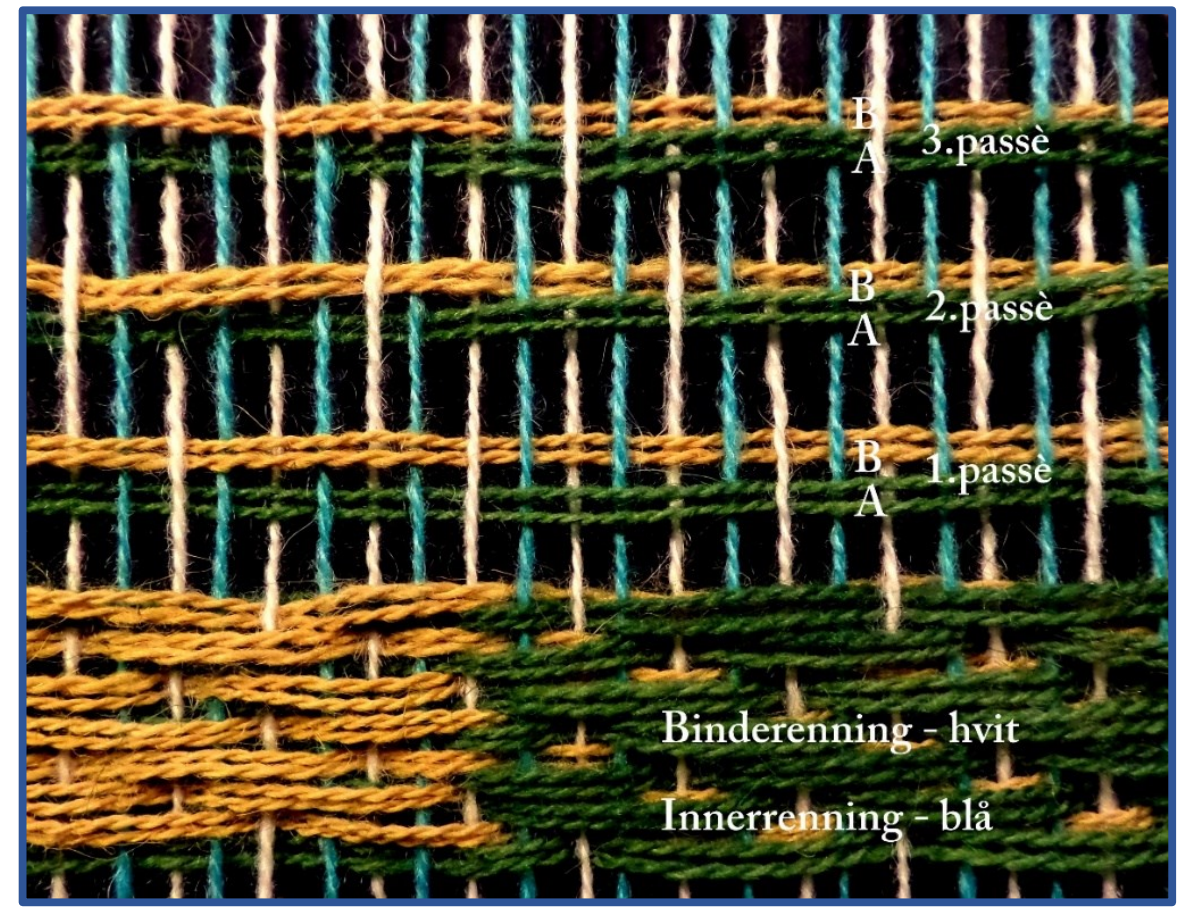

Figure 3. The weaving structure of samitum. The white binding warp binds the wefts to the fabric. The blue inner warp is making the pattern by separating the two wefts $a$ and $b$ in each pass, following a pattern. Photo and illustration, the author.

It is important to know how the samitum works to understand what, and how to draw the pattern. Very often unearthed fabrics has lost all its color, and one have to look for other sign to know how the pattern goes. Good photos are also very important, both to get the overview, and to zoom into small areas for counting the warps and the wefts. I have found mistakes from earlier researchers, not being aware of the inner warp/main warp/filling warp that is not visible on either side of the fabric.

\footnotetext{
${ }^{3}$ Marianne Vedeler, Silks for the Vikings. Ancient textiles series, vol. 15, 2014, Oxbow books, Oxford.
} 
On the figure 3, the blue treads are the inner warp and the white threads are the binding warp, they are stretched in the loom. The white warp are binding the wefts to the fabric in a twill, $1 / 2$ twill, or a tree shafts twill. Each time a shed are open, two wefts in different colors are shuttled. As the figures 3 shows the two wefts, the green and the yellow, goes on each side of the blue warp, switching place according to the pattern. Meaning it is the movement of the blue warp, the inner warp that makes the pattern in the fabric.

Pattern can be picked directly with a stick in the blue warp, or the blue warp are put on heddles and pattern shafts or in a draw loom for repeating pattern. Six warps and six wefts make this simple structure, named samitum from the Greek word hexa mitum meaning six treads. This is the basics, but there were many variations over the nearly 1000 years this structure was used for patterned silk weaving. Different looms and pattern devises was for repeating pattern was developed.

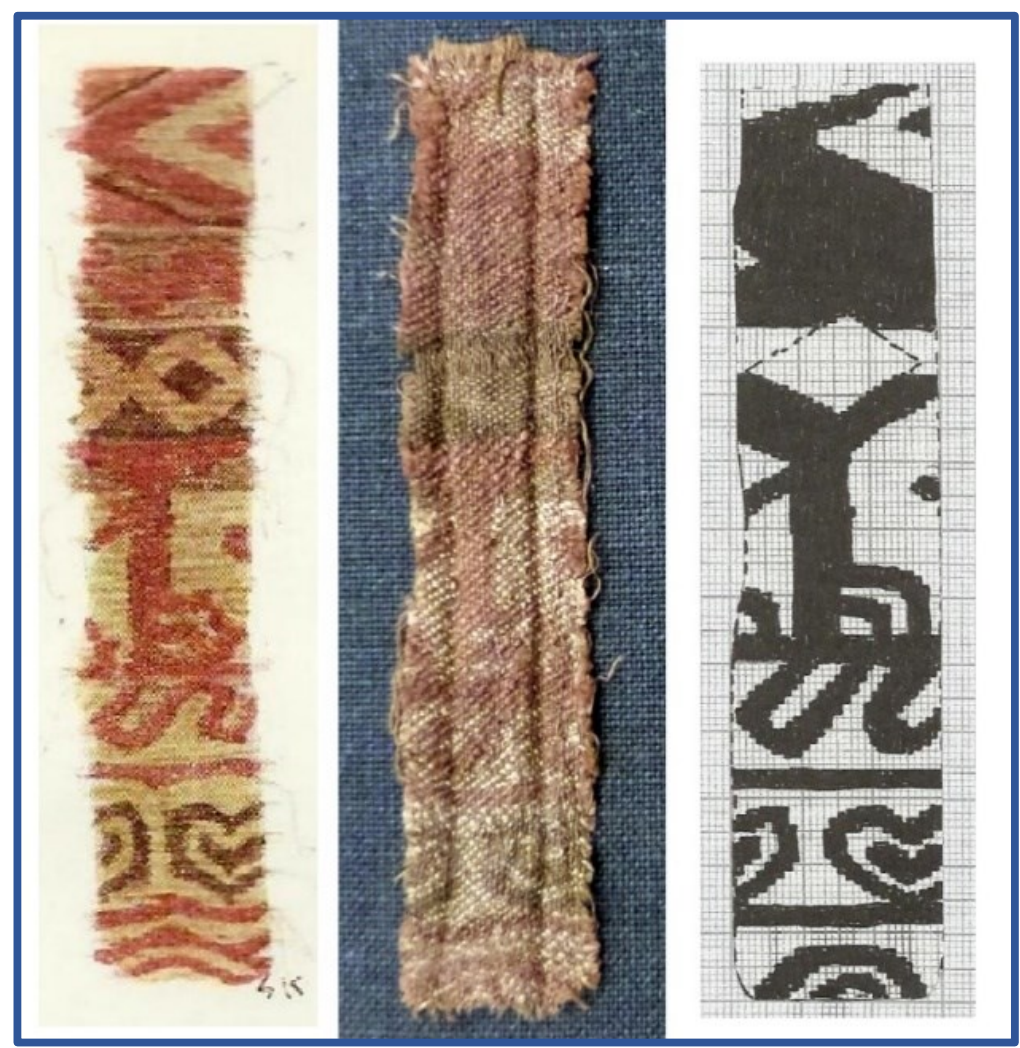

Figure 4. Fragment number 38, to the right a drawing made when the fragments was conserved, photo of the fragment and the drawing on graph paper. Drawing to the left by Sofie Krafft, Photo and black and white drawing by the author.

I started to draw the pattern on fragments on graph paper, each square one inner warp end. Those I could count but because the large variation in the number of wefts per $\mathrm{cm}$ I had to both count and measure the forms. Figure 4 shows fragment number 38, the drawing at the left was done near the time the textiles was unearthed, were there still was some color pigments left. ${ }^{4}$ The drawer did not know the weaving structure, so it was not easy to decide what was pattern, stain, dirt or other impacts.

\footnotetext{
${ }^{4}$ Sofie Krafft, Fra Osebergfunnets tekstiler. Fragmenter av billedvev og silketekstiler med rekonstruerte mønstre. Dreyers forlag, Oslo, 1955.
} 


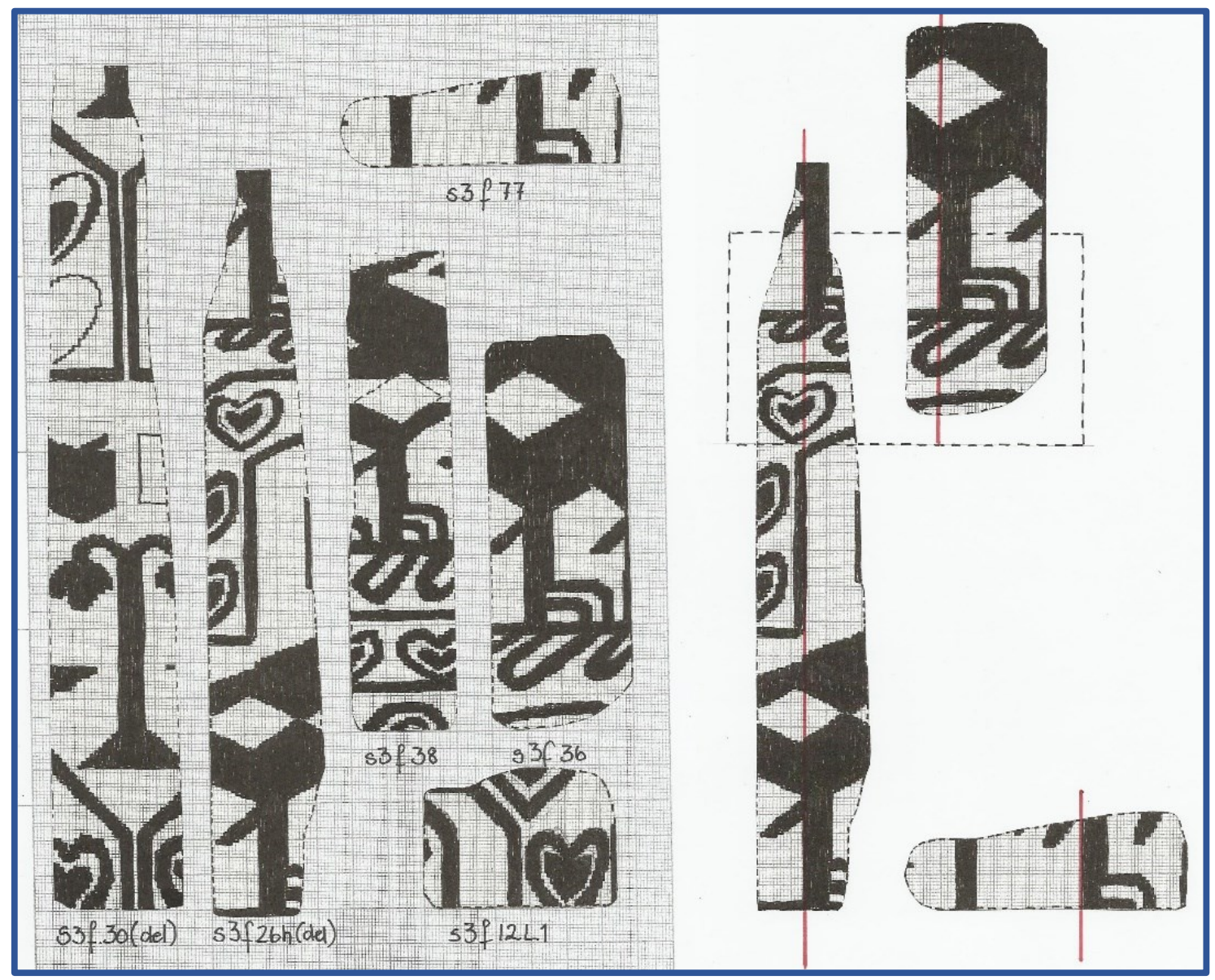

Figure 5. The shapes and drawings on all the fragments noted on the graph paper. Now it was possible to move them around to find out how they could connect and reveal the pattern unit. The figure at the right shows the double warp end, marked by red in three of the fragments. This mistake in the binding warp made the pattern to find. Illustrations by the author.

Six fragments drawn in the same way, so they became compatible. The fragments can come from all over a large fabric, and it is handmade with all the variation that gives. Being handmade also give room for a lot of different marks, and possible mistakes. One mistake, a double warp end could be found in three fragments, as the red line marks to the right, and when the drawings was clear I could see it run through the same spot in a birds foot in all the three fragments.

I concluded that these three fragments was in the same place in warp when the fabric was woven, but in different reports, under or over each other, with the same mistaken warp end running through them. The fragments had different forms, so they covered different parts in the pattern unit. The three other pieces also found their place based on this.

On the drawing to the right figure 5, there is three different repeat of the same object, the birds foot and its surroundings. In the frame, the pattern is similar but clearly not identical. This pattern was most likely repeated mechanically in the weft, but in the warp direction the pattern was picked again for every new report. The pattern unit was not stored, like today weaving on a draw loom with pattern shafts. 

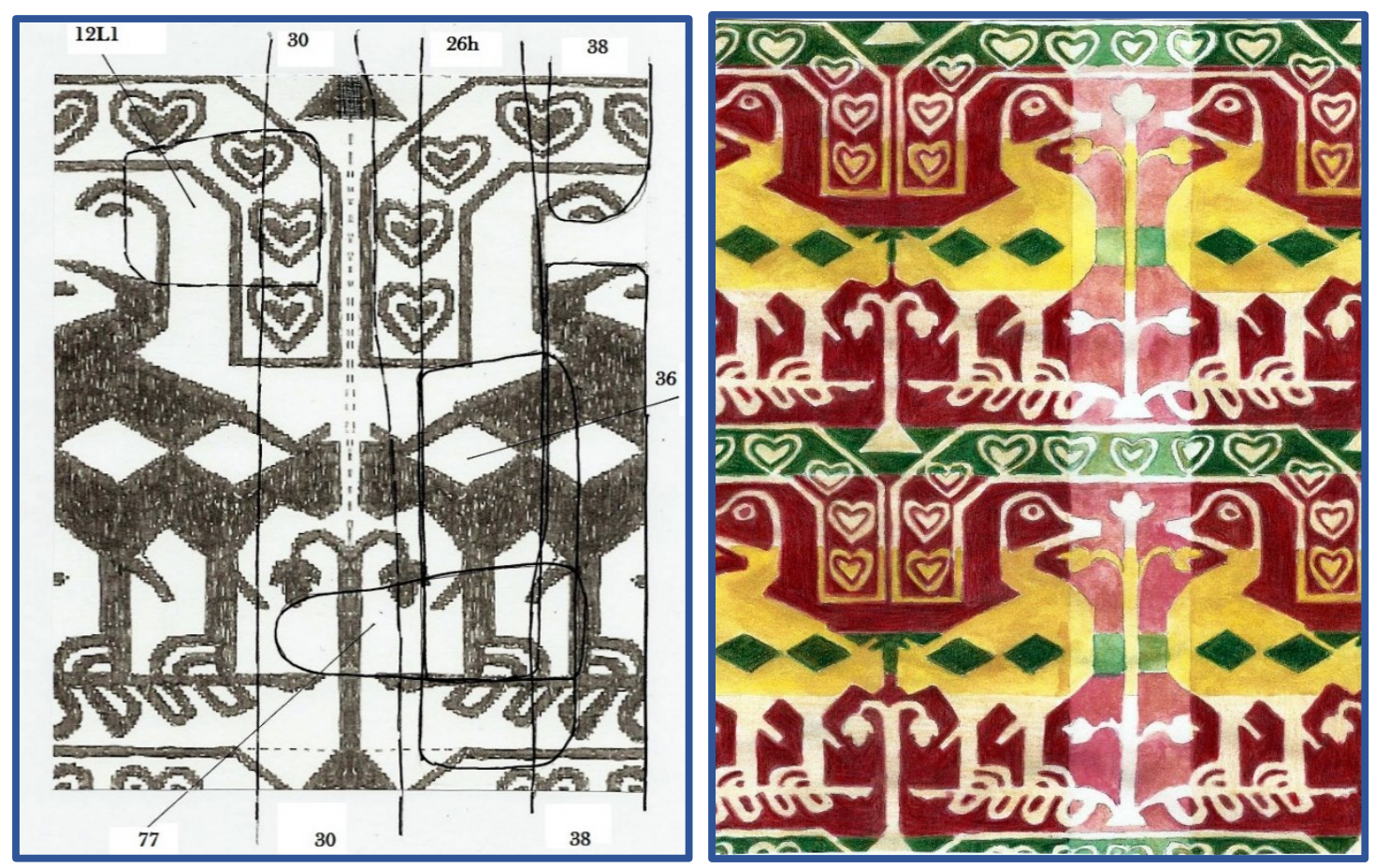

Figure 6. The six fragments made this pattern unit, the fragments also showed the mirrored repeat. Fragment 38 had two spots showing that there were one or two objects between the birds where they was standing beak to beak. Illustration by the author.

Figure 7. Water colored sketch of the pattern, in the pale areas there is no information about the pattern. The color is showing how the colors changes in the weft in both the pattern and background in the fabric. Illustration by the author.

The six fragments could not give me the whole pattern unit, but the fragments number 38 told me that there was one or two objects between the birds were they was standing beak to beak. On the drawing, I have put a possible object between the birds, marked with weaker colors.

Before I could weave a sample, I had to find out how the colors were in the fabric. The fabric had just two wefts in the pass, as shown on figure 3, one for the pattern a and one for the background $\mathrm{b}$. The color in the pattern a changes in broad white and yellow stripes, and the background b changes in broad red and narrow green/blue or black stripes, see figure 7.
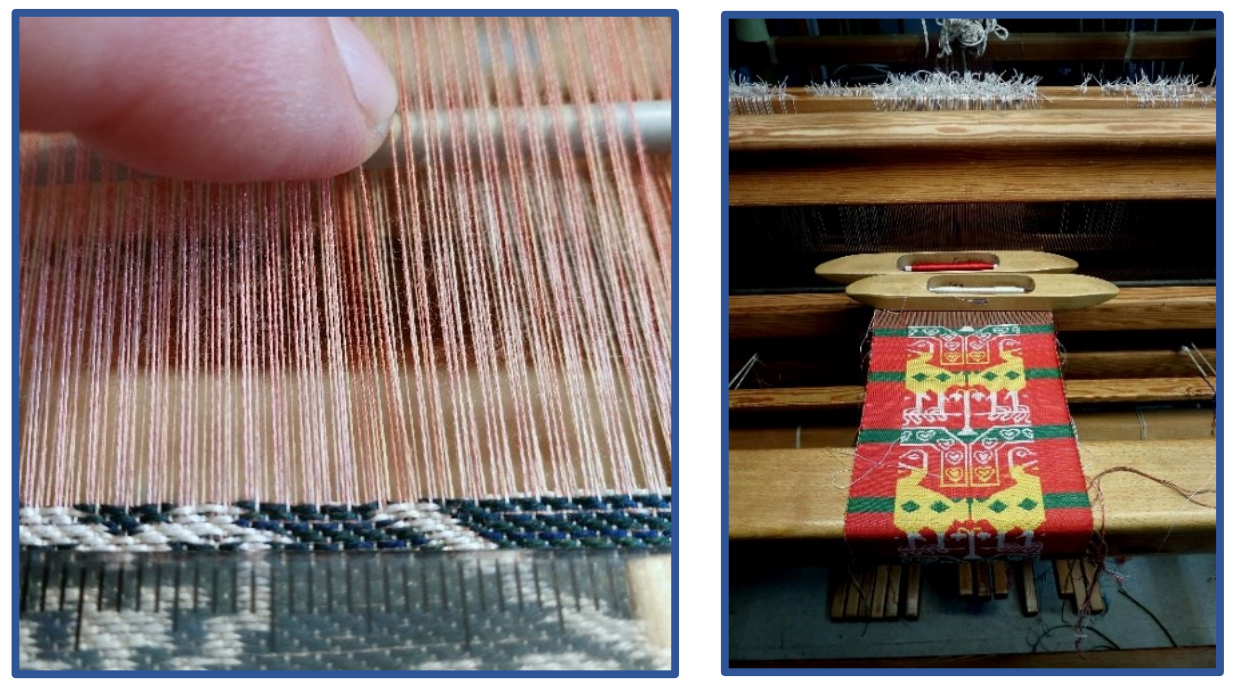

Figure 8.- 9. is showing the work in the loom. To help me separate the inner warp, where I picked the pattern from the binding warp I gave them different colors. This is not visible in the fabric. Photos the author. 
Known samitum silks, have the same way of changing colors at certain places in the pattern unit. The large variation of wefts per $\mathrm{cm}$ made me both count and measure to place the stripes. The original silk yarn was handmade, some yarn just reeled and some slightly spun. The yarn was of dyed with pigments from minerals and plants. I did not have the possibility to investigate that, and used materials proposed like the original, to get the right density in warp and weft, and used reactive dying pigments to the color the yarn.

The weavers of this original fabric did not work in a loom like mine. ${ }^{5}$ Sitting there picking the pattern in the warp, I remember the Danish weaver and researcher John Becker, in his book "Pattern and loom," told about a fragment in Victoria and Albert museum in London, where taquete and tapestry weaving was used in the same fabric. ${ }^{6}$ There is even a similar fragment in the Royal Ontario Museum, in Toronto, described by Dorothy Burnham. I decided that I had to try weaving samitum on a vertical loom, more special, at least to day for tapestry weaving.

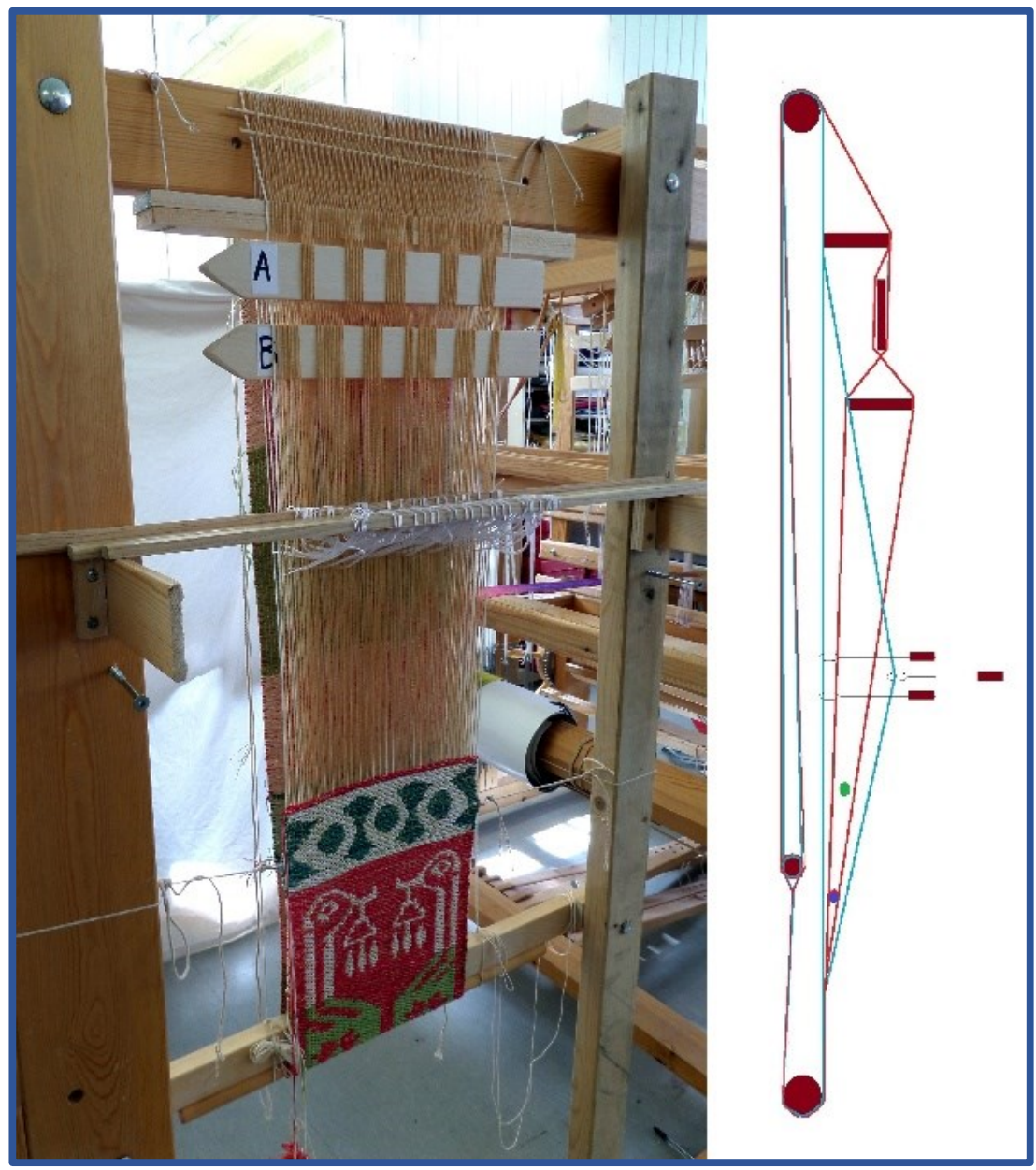

Figure 10. Samitum woven in a vertical warp. A beam is raising the here red inner warp over the here blue binding warp. The pattern is picked in the inner warp at the top of the loom. When the bindings shaft is raised two weft is passing the sheds, first a then $b$. See footnote 7. Photo the author.

\footnotetext{
${ }^{5}$ The weaving process, https://www.youtube.com/watch?v=SkO9sh6bHzs.

${ }^{6}$ John Becker, Pattern and Loom (Rhodos International Publishers, Copenhagen, 1987), 83.
} 

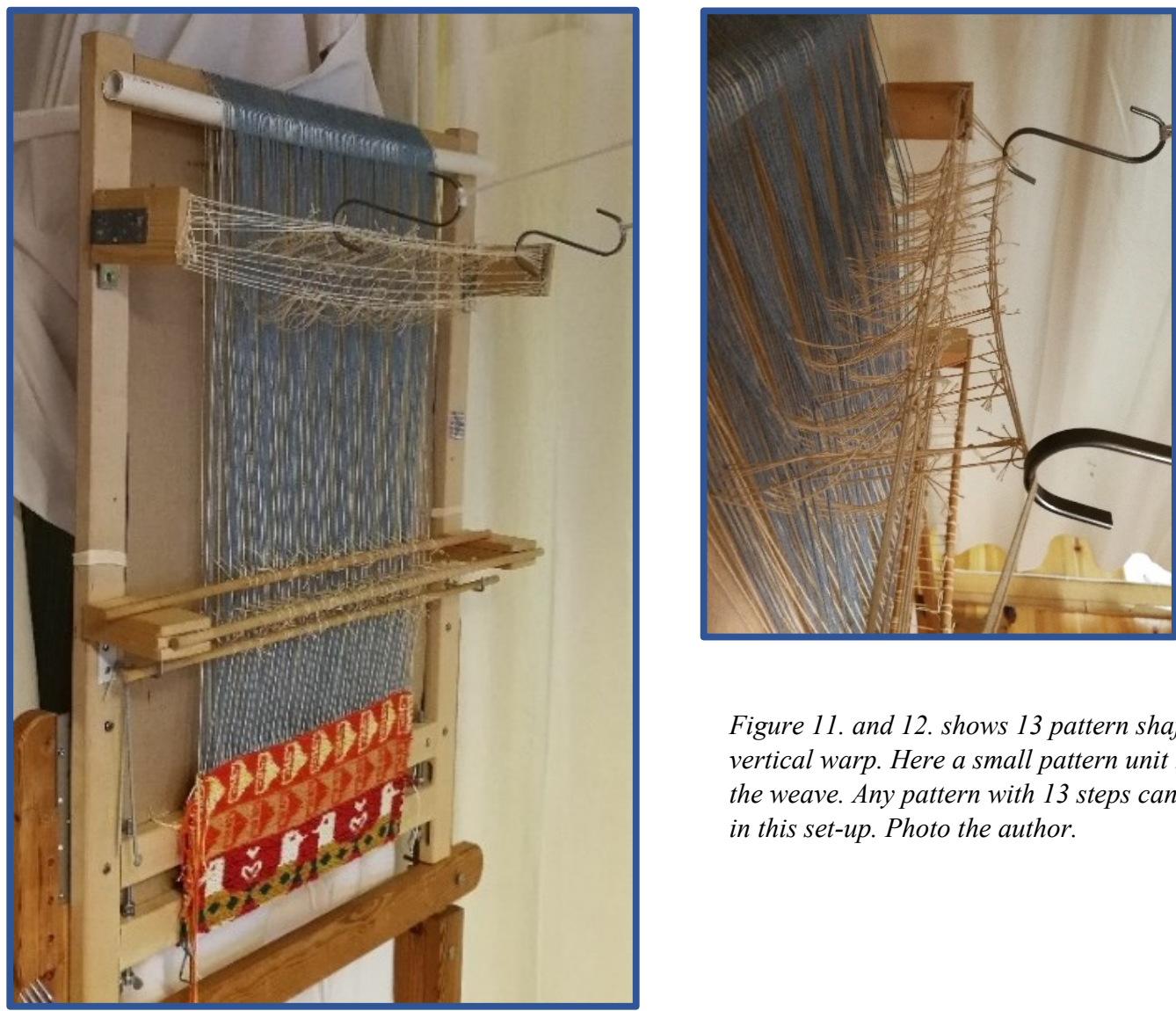

Figure 11. and 12. shows 13 pattern shafts on a vertical warp. Here a small pattern unit repeats in the weave. Any pattern with 13 steps can be woven in this set-up. Photo the author.

Figure 10 shows my first attempt on this vertical setup, just an improvised model. It really took me some time to find out how to weave, but once I understood, it was easier to weave here than in my Nordic flat loom. At the top of loom, a beam is lifting the inner warp over the white binding warp. In this upper area, I can pick the pattern a on a stick, and then lifting one twill shaft to make the shed for the pattern weft a. For the weft $b$, one has to pick the counter warp ends, the opposite from a on the stick, the twill shaft will be the same. The weft $b$ is now completing this pass. For better to understand this I made a demonstration. ${ }^{7}$

My attempt was based on a hypothetical idea, but the fact is that there are looms operating like this. The so-called zilu-loom is probably in use in Iran and Egypt even today. ${ }^{8}$ This looms have thick ropes serving as pattern shafts crossing the warp some decimeter over it. Each inner warp end are attached to the "shafts" by heddles, in a numerically system like in the draw loom for making damask with pattern shafts. Two shafts operate the binding warp in

\footnotetext{
${ }^{7}$ Weaving on this vertical set up https://www.youtube.com/watch?v=YeFN_ScbLFU.
}

\footnotetext{
${ }^{8}$ Angela Sheng Chinese silk that circulated among peoples north and west. Berit Hildebrandt og Carole Gillis (red.) Silk, Trade and Exchange along the Silk Roads between Rome and China in Antiquity (Oxbow Books, Oxford, 2017), 111.
} 
a tabby. Figure $\mathrm{xx}$ is showing a model of this system with separated pattern shafts, and shafts for the ground

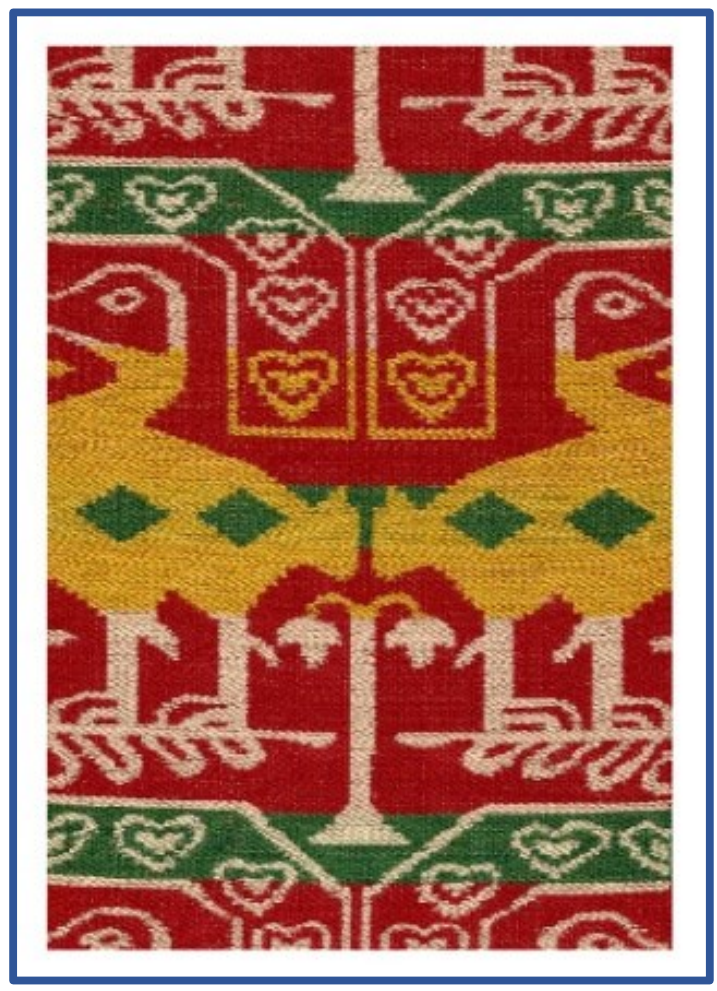
binding, here a tree shaft twill.

Figure 13. The pattern is simple compared with other samitum silks made in the same period. By counting the inner warp ends moving separately there is no reason to say that fabric 3 was woven with simple tools. Photo and textile, the author.

The pattern on Fabric 3 is simple compared with some other samitum silks made in the same period and with a similar pattern. ${ }^{9}$ There is no outlines around the shapes as common in these silks, and the figures are quite simple. It may be easy to assume that it was woven on a simple loom, with less options, but in fact, by counting the inner warp ends in the pattern unit that has been separately used in making the pattern, it is the approximately the same number of inner warp ends as in the compared silk.

Conclusion. I have fulfilled my dream of weaving or copying a samitum silk. As my weaving colleagues in the Viking Age in Norway, I was also unfamiliar with silk material and tools used to weave the silk fabrics found in the Oseberg burial. This work gave the possibility to understand the development of weaving tools I have not thought about, the long line of history from picking a pattern with a sticks, actually as I do today, to devises for repeating a pattern. All the way from the device that could repeat a pattern unit just in the weft, to the draw loom, the jacquard and to the digital handloom.

It is not easy to describe the fabric I wanted to feel and understand. The patterned silk fabric in samitum was soft, dense and have a heavy quality. It gives a meaning for me as a weaver to come closer to the history of textile, and use my practical knowledge as another way of investigate these textiles.

The collection of samitum silks in the Oseberg is not homogeny, and one will learn more trying by copying more of the fabrics. At least four or five of them has as many fragments as number 3 .

\footnotetext{
${ }^{9}$ Viking 2017, With silk for Valhall. Åse Eriksen, 54 http://samitum.no/index_files/medsilke.pdf
} 
Bibliography

Becker, John. Pattern and Loom. Rhodos International Publishers, Copenhagen, 1987.

Emil, Christensen Arne og Margareta Nockert (red.) Osebergfunnet, bind IV. Tekstilene. Kulturhistorisk museum, Universitetet i Oslo, Oslo, (2006).

Geijer, Agnes. Ur textilkonstens historia. 4. opplag. Gidlunds Förlag, Ljubliana (2006).

Hildebrandt, Berit og Carole Gillis (red.) Silk, Trade and Exchange along the Silk Roads between Rome and China in Antiquity. Oxbow Books, Oxford. 2017.

Krafft, Sofie. Fra Osebergfunnets tekstiler. Fragmenter av billedvev og silketekstiler med rekonstruerte mønstre. Dreyers forlag, Oslo (1955).

Vedeler, Marianne. Silks for the Vikings. Ancient textiles series, vol. 15. Oxbow books, Oxford, 2014.

Viking 2017, With silk for Valhall. Åse Eriksen, 54

http://samitum.no/index_files/medsilke.pdf 